\title{
PENGARUH COST OF LOANABLE FUND (COLF) DAN TINGKAT SUKU BUNGA SERTIFIKAT BANK INDONESIA (SBI) TERHADAP JUMLAH KREDIT YANG DIBERIKAN
}

(Studi Kasus Pada PT. Bank Mandiri, Tbk periode Januari 2000 - Desember 2012)

\author{
Effect of Cost of Loanable Fund (COLF) and Rate of Interest Rate of Bank \\ Indonesia Certificate (SBI) on Total Credits Provided \\ (Case Study At Pt Bank Mandiri, Tbk Period J anuary 2000 - December 2012)
}

\author{
Erisandi, S.E., M.M. \\ Jurusan Administrasi Niaga, Universitas Tulang Bawang Lampung \\ Email: eri_sandi@rocketmail.com
}

\begin{abstract}
Abstrac
This study aims to analyze the effect of the Cost of Loanable Fund (COLF) and the interest rate of Bank Indonesia Certificates (SBI) on the amount of credit granted. This research was conducted on PT.Bank Mandiri, Tbk 2000 - 2012.

The results showed that partially Cost of loanable funds affect the amount of credit significantly while partially the interest rate of Bank Indonesia Certificates has no effect on the amount of credit significantly. Meanwhile, simultaneous test results show the Cost of loanable Fund and SBI have a significant effect on the amount of Loans Provided.

The advice given to Bank Mandiri is that the bank management must be able to maintain the appropriate Cost of loanable Fund value. This is because based on the results of empirical research in the field of Cost of loanable funds have a strong and strong correlation to the amount of credit provided, in relation to the SBI which is a factor Given and Bank Indonesia policy, Bank Mandiri must be able to follow and make appropriate policies to improve the credit given at the optimum point.
\end{abstract}

Keywords: Cost of loanable Fund, Bank Indonesia Certificates, Total Credit

\begin{abstract}
Abstrak
Penelitian ini bertujuan untuk menganalisa pengaruh Cost of Loanable Fund (COLF) dan tingkat suku bunga Sertifikat Bank Indonesia (SBI) terhadap jumlah kredit yang diberikan. Penelitian ini dilakukan pada PT.Bank Mandiri,Tbk tahun $2000-2012$.

Jenis penelitian yang digunakan adalah deskriptif dan kuantitatif. Metode pengumpulan data yang digunakan adalah metode observasi lapangan guna mendapatkan data sekunder.

Hasil penelitian menunjukan bahwa secara parsial Cost of loanable Fund berpengaruh terhadap Saran yang diberikan kepada Bank Mandiri adalah pihak manajemen bank harus mampu menjaga nilai Cost of loanable Fund yang tepat. Hal ini dikarenakan berdasarkan hasil penelitian empiris dilapangan Cost of loanable Fund berpengaruh dan berhubungan kuat terhadap Jumlah Kredit yang diberikan, dalam kaitannya dengan SBI yang merupakan factor Given dan kebijakan Bank Indonesia maka Bank Mandiri harus mampu mengikutinya dan melakukan kebijakan yang bersesuaian guna meningkatkan kredit yang diberikan pada titik yang optimum.
\end{abstract}

Kata Kunci : Cost of loanable Fund, Sertifikat Bank Indonesia, Jumlah Kredit 


\section{PENDAHULUAN}

Pesatnya perkembangan dunia usaha dewasa ini menuntut agar peranan lembaga keuangan, khususnya bank untuk lebih aktif. Peran aktif bank tersebut terutama dalam mengatur peredaran uang, menghimpun dana dari unit surplus (yaitu pihak-pihak yang memiliki kelebihan dana) dan menyalurkan kembali dana tersebut ke unit deficit (yaitu pihak-pihak yang memerlukan dana). Kegiatan tersebut lebih dikenal dengan istilah financial intermediary / lembaga intermediasi.

Kegiatan yang telah disebutkan di atas merupakan kegiatan pokok bank, seperti telah ditegaskan dalam Undang-Undang Nomor 10 tahun 1998 perubahan dari Undang-Undang Nomor 7 tahun 1992 tentang Perbankan, yang menyatakan bahwa bank adalah badan usaha yang menghimpun dana dari masyarakan dalam bentuk simpanan dan menyalurkannya kepada masyarakat dalam bentuk kredit dan atau bentuk-bentuk lainnya dalam rangka meningkatkan taraf hidup orang banyak.

Wujud dari usaha pokok tersebut, bank menciptakan produk seperti tabunga, giro, deposito, dan sebagainya dalam rangka menghimpun dana. Keberhasilan bank dalam menghimpun dana dari masyarakat secara tidak langsung menunjukkan keadaan dan kondisi bank itu sendiri. Dana yang telah berhasil dihimpun oleh bank dialokasikan dalam berbagai bentuk pengalokasian dana, salah satunya adalah pemberian kredit. Usaha perkreditan ini merupakan tangkaian kegiatan utama suatu bank, dimana pemberian kredit ini merupakan rangkaian kegiatan utama suatu bank, dimana pemberian kredit adalah tulang punggung kegiatan perbankan. Hal ini dapat dilihat dari struktur aktiva sebuah bank, bahwa unsure penempatan dana bank pada portfolio kredit mencakup porsi yang meliputi sekitar $70 \%$ hingga $80 \%$ dari seluruh aktiva bank.
Dalam pemberian kredit, bank menetapkan tingkat suku bunga atau Base Lending Rate $(B L R)$ guna meningkatkan profitabilitas. Adapun salah satu komponen yang menentukan Base Lending Rate adalah Cost of Loanable Fund (COLF) yaitu Biaya Dana yang harus dibayar oleh bank untuk setiap rupiah dana setelah dikurangi dengan bagian dana yang harus dipelihara bank sebagai cadangan wajib. Jika Cost of Loanable Fund pada suatu bank rendah maka secara tidak langsung akan mengakibatkan turunnya besaran Base Lending Rate. Dengan Base Lending Rate yang rendah, bank dapat melakukan kegiatan operasional yang lebih mencerminkan tingkat efisiensinya yang tinggi yang dapat mengundang datangnya rasa kepercayaan yang tinggi dari masyarakat terhadap manajemen bank yang bersangkutan.

Sebaliknya Base Lending Rate yang tinggi akibat Cost of Loanable Fund tinggi maka mencerminkan tingkat efisien yang rendah dalam operasional bank. Penerapan Base Lending Rate yang tinggi pun dapat mengakibatkan terjadinya credit risk, hal tersebut juga dapat menyebabkan turunnya kepercayaan masyarakat terhadap manajemen bank yang bersangkutan (Masyhud Ali, 2004: 233-234). Selain itu, bank juga dapat kehilangan debitur. Karena, debitur akan mencari bank lain yang mampu menawarkan bunga kredit yang relatif lebih rendah.

Namun saat dimana industri perbankan menghadapi situasi perekonomian yang seolah tidak menentu dan penuh dengan ketidakpastian, pemberian kredit oleh bank kepada masyarakat sedikit tersendat. Pengalaman adanya kredit macet akhirakhir ini telah memacu kalangan perbankan untuk lebih berhati-hati dalam mengatur alokasi dananya pada kredit. Oleh karena itu kalangan industri perbankan saat ini cenderung lebih menyukai untuk mengalokasikan dananya dalam bentuk cadangan sekunder yang dalam hal ini dialokasikan pada surat-surat berharga 
terutama pada Sertifikat Bank Indonesia (SBI). Karena Sertifikat Bank Indonesia (SBI) tidak dibatasi oleh permintaan, sedangkan tingkat suku bunga lebih menjanjikan dengan tingkat risiko yang rendah daripada dialokasikan pada kredit untuk masyarakat.

Selain itu Sertifikat Bank Indonesia (SBI) dianggpa tdak terbatas, pasarnya luas dan tingkat diskontonya tidak dapat dipengaruhi oleh suatu bank manapun yang ikut lelang. Bahkan penempatan dana dalam Sertifikat Bank Indonesia (SBI) tersebut dapat memberikan pendapatan kepada bank yang setiap saat dapat dijadikan uang tunai tanpa mengakibatkan kerugian pada bank yang bersangkutan.

\section{METODE PENELITIAN}

\section{Pengertian Bank}

Dalam suatu tatanan perekonomian dibutuhkan sebuah lembaga keuangan yang mempunyai fungsi pokok menghimpun dana dan menyalurkan dana, lembaga keuangan yang memiliki fungsi demikian adalah perbankan. Bank sebagai badan usaha dalam menjalankan usahanya tidak hanya berfokus pada pencarian keuntungan, namun juga bertujuan mewujudkan stabilitas keuangan yang pada akhirnya akan menunjang pembangunan perekonomian dalam sebuah Negara.

Bank secara sederhana dapat diartikan sebagai Lembaga keuangan yang kegiatan utamanya menghimpun dana dari masyarakat dan menyalurkan kembali dana tersebut ke masyarakat serta memberikan jasa bank lainnya.

Definisi bank menurut Kasmir (2004: 8)

"Bank adalah lembaga keuangan yang menjadi lembaga perantara antara masyarakat yang kelebihan dana dengan masyarakat yang kekurangan dana".

Menurut Dendawijaya (2003: 5) yang mengutip dari G.M. Verryn Stuart,
"Bank adalah suatu badan yang bertujuan untuk memuaskan kebutuhan kredit, baik dengan alat-alat pembayarannya sendiri atau dengan uang yang diperolehnya dari orang lain, maupun dengan jalan memperedarkan alat-alat penukar baru berupa uang giral".Menurut UndangUndang RI No.10 tahun 1998 tanggal 10 November 1998 tentang Perbankan, bank didefinisikan sebagai

"Badan usaha yang menhimpun dana dari masyarakat dalam bentuk simpanan dan menyalurkannya kepada masyarakat dalam bentuk kredit dan atau bentuk-bentuk lainnya dalam rangka meningkatkan taraf hidup rakyat banyak"

Dari uraian di atas dapat dijelaskan bahwa bank merupakan perusahaan yang bergerak dalam bidang keuangan yang memiliki kegiatan pokok menghimpun dana dari masyarakat atau pihak lainnya dalam bentuk simpanan (funding), menyalurkan dana kepada masyarakat atau pihak lainnya dalam bentuk kredit (lending), dan juga menyediakan jasa-jasa keuangan lainnya (service).

\section{Pengertian Cost of Loanable Fund}

Salah satu pengalokasian dana yang merupakan sumber pendapatan terbesar bagi bank adalah kredit. Dalam pemberian kredit, bank menetapkan tingkat bunga atau Base Lending Rate (BLR) kepada debitur guna meningkatkan profitabilitas. Salah satu komponen yang menentukan besaran Base Lending Rate (BLR) adalah Cost of Loanable Fund. Tinggi rendahnya Cost of Loanable Fund akan mempengaruhi besarnya tingkat suku bunga kredit. Hal ini juga akan berdampak pada perkembangan jumlah kredit yang diberikan pada bank tersebut.

Definisi Cost of Loanable Fund menurut Dendawijaya (2003:13) adalah:

"Cost of Loanable Fund adalah biaya dana yang harus di bayar oleh bank untuk setiap rupiah dana setelah dikurangi dengan 
bagian dana yang harus dipelihara bank sebagai cadangan wajib."

Firdaus dan Ariyanti (2004:72) mendefinisikan:

"Cost of Loanable Fund adalah semua biaya bunga yang dibayarkan untuk setiap rupiah dana yang dikumpulkan oleh bank baik dalam bentuk simpanan maupun pinjaman/ kredit dari pihak lain, termasuk dana yang tidak dioperasionalkan dan menjadi non earning assets, baik untuk giro wajib minimum maupun untuk reserve/ cadangan lain sesuai kebutuhan bank yang bersangkutan."

Sedangkan menurut Dahlan Siamat (2001:122):

"Cost of Loanable Fund adalah biaya dana setelah dikurangi ketentuan reserve requirement".

Berdasarkan definisi-definisi Cost of Loanable Fund di atas, maka dapat disimpulkan bahwa Cost of Loanable Fund adalah sejumlah biaya yang dikeluarkan oleh bank untuk setiap rupiah dana yang berhasil dihimpunnya setelah dikurangi dengan Giro Wajib Minimum dan juga merupakan salah satu faktor yang menentukan kebijakan harga atas dana yang akan dipinjamkan.

\section{Konsep Perhitungan Cost of Loanable Fund}

Bank perlu menghitung berapa besarnya Cost of Loanable Fund untuk mengetahui dana yang benar-benar efektif dapat dipergunakan untuk pemberian kredit, sehingga bank mampu menyeimbangkan antara biaya yang harus dikeluarkan dengan tingkat keuntungan yang diharapkan dan mampu bersaing dengan bank-bank lainnya.

Menurut George Hampel (2001) ada beberapa alasan perlunya bank menghitung biaya dana yang digunakannya.
1. Bank mencari kombinasi sumber dana dengan biaya terendah yang tersedia di pasar.

2. Perhitungan biaya dana yang akurat penting untuk menentukan besarnya keuntungan yang diperoleh atas aktiva produktifnya.

3. Jenis sumber dana yang dihimpun bank dan penggunaannya memiliki dampak terhadap risiko likuiditas, risiko tingkat suku bunga, dan risiko modal bank.

Perhitungan Cost of Loanable Fund berdasarkan metode Weighted Average Cost of Fund atau Biaya Dana Rata-Rata Tertimbang dijabarkan oleh Dendawijaya (2003:106) sebagai berikut:

a. Menetapkan tingkat bunga yang akan dibayar kepada deposan

b. Menghitung komposisi sumber dana

c. Memperhatikan ketentuan tentang Reserve Requirement (RR)

d. Menghitung biaya dana efektif, dengan rumus:

$$
\frac{100 \%}{100 \%-R R} \times \text { tingkat bunga }
$$

e. Menghitung kontribusi biaya dana, dengan rumus:

Komposisi Dana $x$ Biaya dana Efektif

f. Menjumlahkan seluruh kontribusi biaya dana untuk memperoleh tingkat Cost of Loanable Fund

\section{Pengertian Sertifikat Bank Indonesia (SBI)}

Ketentuan tentang penertiban Sertifikat Bank Indonesia (SBI) semula diatur dengan SK Direksi BI No. 16/55/KEP/DIR dan SEBI No. 16/8/UPUM, keduanya tertanggal 21 Januari 1984. Ketentuan itu kemudian disempurnakan dengan SK Direksi BI No. 21/52/KEP/DIR dan SEBI No. 21/30/UPG, keduanya tertanggal 27 Oktober 1988, dan merupakan salah satu ketentuan Pakto 1988. 
Pengertian Sertifikat Bank Indonesia menurut Taswan (2003:160):

"Sertifikat Bank Indonesia adalah surat berharga atas unjuk dalam rupiah yang diterbitkan oleh Bank Indonesia sebagai pengakuan hutang berjangka waktu pendek dengan sistem diskonto".

Menurut Widjarto (2001:197):

"Sertifikat Bank Indonesia adalah surat berharga atas unjuk dalam rupiah yang diterbitkan dengan sistem diskonto oleh Bank Indonesia sebagai pengakuan hutang berjangka waktu pendek".

Sejalan dengan ide dasar penerbitan SBI sebagai salah satu piranti operasi pasar terbuka, penjualan SBI diprioritaskan kepada lembaga perbankan. Meskipun demikian, tidak tertutup kemungkinan masyarakat baik perorangan maupun perusahaan untuk dapat memiliki SBI. Pembelian SBI oleh masyarakat tidak dapat dilakukan secara langsung dengan Bank Indonesia melainkan harus melalui bank umum serta pialang pasar modal yang ditunjuk oleh Bank Indonesia.

Ada beberapa istilah berkaitan dengan instrumen SBI, yaitu:

1. SBI Lelang, yaitu SBI yang dijual lelang kepada bank atau pialang yang didasarkan atas target kuantitas dalam rangka pelaksanaan kebijakan pengendalian moneter.

2. SBI Repo (Repurchase Agreement) adalah SBI yang dibeli kembali oleh Bank Indonesia dalam rangka memenuhi kebutuhan likuiditas bank dengan perjanjian bank akan membeli kembali sesuai jangka waktu repo yang telah diperjanjikan.

\section{Pengertian Kredit}

Kredit merupakan sarana bagi perbankan dalam menjalankan perannya sebagai lembaga intermediasi. Peranannya sebagai lembaga intermediasi ini merupakan unsur yang utama diantara peranan lainnya dalam memperlancar lalu lintas pembayaran dan memberikan jasa pelayanan perbankan bagi masyarakat

Pelaksanaan peranannya itu dilakukan dengan menghimpun dana-dana dari unit surplus dan menyalurkannya kembali pada masyarakat dan dunia usaha yang merupakan unit defisit yang memerlukan untuk berbagai kegiatan mulai dari yang bersifat konsumtif hingga yang bersifat produktif.

Kegiatan kredit tidak semata mengandung unsur yang menghasilkan interest income bagi bank, tetapi juga menjadi unsur yang memberikan dorongan bagi berkembangnya kegiatan perekonomian masyarakat.Menurut Firdaus dan Ariyanti (2004:1)

"Istilah kredit berasal dari bahasa Yunani (cedere) yang berarti kepercayaan. Dengan perkataan lain maka kredit mengandung pengertian adanya suatu kepercayaan dari seseorang atau badan yang diberikan kepada badan atau seseorang lainnya yaitu bahwa yang bersangkutan pada masa yang akan datang akan memenuhi segala sesuatu kewajiban yang telah diperjanjikan terlebih dahulu".

Definisi kredit menurut Mac Leod adalah:

"Kredit adalah suatu reputasi yang dimiliki seseorang, yang memungkinkan ia bisa memperoleh uang, barang-barang atau buruh/tenaga kerja, dengan jalan menukarkannya dengan suatu janji untuk membayarnya di suatu waktu yang akan datang".

Raymon P. Kent dalam buku karangannya Money and Banking mengatakan bahwa:

"Kredit adalah hak untuk menerima pembayaran atau kewajiban untuk melakukan pembayaran pada waktu diminta, atau pada waktu yang akan datang, karena penyerahan barang-barang sekarang". 
Menurut Undang-Undang No. 10 tahun 1998 tentang perbankan.

"Kredit adalah penyediaan uang atau tagihan yang dapat dipersamakan dengan itu, berdasarkan persetujuan atau kesepakatan pinjam meminjam antara bank dengan pihak lain yang mewajibkan pihak peminjam untuk melunasi utangnya setelah jangka waktu tertentu dengan pemberian bunga".

Dengan demikian dapat disimpulkan, bahwa kredit adalah kepercayaan untuk menyediakan uang, barang atau jasa kepada seseorang atau badan dengan persetujuan atau kesepakatan bahwa pihak peminjam / yang bersangkutan akan melunasi kewajibannya sesuai jangka waktu yang telah disepakati dengan memberikan imbalan / bunga.

\section{Tujuan Kredit}

Dalam membahas tujuan kredit tidak terlepas dari falsafah yang dianut oleh suatu negara. Oleh karena itu tujuan kredit tidak semata-mata hanya mencari keuntungan, melainkan disesuaikan dengan tujuan Negara yaitu untuk mencapai masyarakat adil dan makmur berdasarkan Pancasila. Dengan demikian maka tujuan kredit yang diberikan oleh suatu bank adalah untuk :

a. Turut menyukseskan program pemerintah di bidang ekonomi dan pembangunan.

b. Meningkatkan aktivitas perusahaan. Agar dapat menjalankan fungsi menjamin terpenuhinya kebutuhan masyarakat.

c. Memperoleh laba agar kelangsungan hidup perusahaan terjamin, dan dapat memperluas usahanya.

Dari tujuan tersebut, dapat disimpulkan adanya kepentigan yang seimbang antara kepentingan pemerintah, masyarakat (rakyat), dan pemilik modal (pengusaha).

\section{HASIL DAN PEMBAHASAN}

\section{Cost of Loanable Fund}

Cost of Loanable Fund adalah sejumlah biaya yang dikeluarkan oleh bank untuk setiap rupiah dana yang berhasil dihimpunnya setelah dikurangi dengan Giro Wajib Minimum dan juga merupakan salah satu faktor yang menentukan kebijakan harga atas dana yang akan dipinjamkan. Gambaran nilai Cost of Loanable Fund pada Bank Mandiri tahun 2000 - 2012 adalah sebagai berikut

\section{Gambar}

Cost of Loanable Fund Bank Mandiri tahun

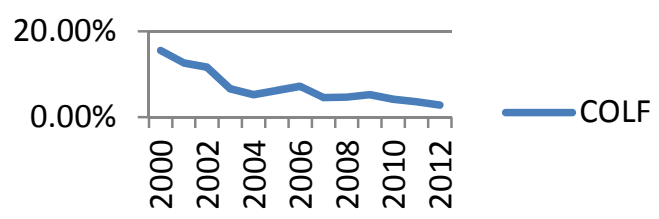

$2000-2012$

Berdasarkan gambar diatas, dapat terlihat bahwa terdapat kecenderungan penurunan Cost of Loanable Fund tiap tahunnya. Nilai Cost of Loanable Fund terendah terdapat pada tahun 2012 yaitu sebesar 0,028. Sedangkan nilai Cost of Loanable Fund tertinggi terdapat pada tahun 2000 yaitu sebesar 0,155.

\section{Tingkat Suku Bunga Sertifikat Bank Indonesia}

Sertifikat Bank Indonesia adalah surat berharga atas unjuk dalam rupiah yang diterbitkan dengan sistem diskonto oleh Bank Indonesia sebagai pengakuan hutang berjangka waktu pendek. Gambaran nilai tingkat suku bunga Sertifikat Bank Indonesia pada Bank Mandiri tahun 2000 2012 adalah sebagai berikut. 


\section{Gambar}

\section{Tingkat Suku Bunga Sertifikat Bank} Indonesia tahun 2000-2012

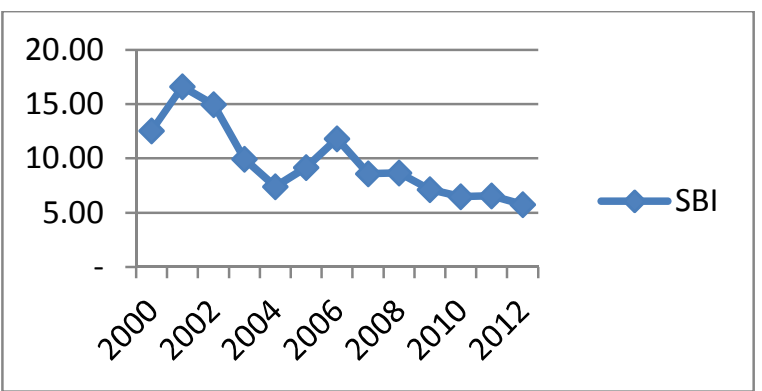

Berdasarkan gambar diatas, dapat terlihat bahwa terdapat kecenderungan penurunan tingkat suku bunga Sertifikat Bank Indonesia. Nilai tingkat suku bunga Sertifikat Bank Indonesia terendah terdapat pada tahun 2012 yaitu sebesar 5,77. Sedangkan nilai tingkat suku bunga Sertifikat Bank Indonesia tertinggi terdapat pada tahun 2001 yaitu sebesar 16,62.

\section{Jumlah Kredit Yang Diberikan}

Kredit adalah kepercayaan untuk menyediakan uang, barang atau jasa kepada seseorang atau badan dengan persetujuan atau kesepakatan bahwa pihak peminjam / yang bersangkutan akan melunasi kewajibannya sesuai jangka waktu yang telah disepakati dengan memberikan imbalan / bunga. Gambaran jumlah kredit yang diberikan pada Bank Mandiri tahun 2000 - 2012 adalah sebagai berikut.

\section{Gambar}

Jumlah Kredit yang Diberikan Bank Mandiri tahun $2000-2012$

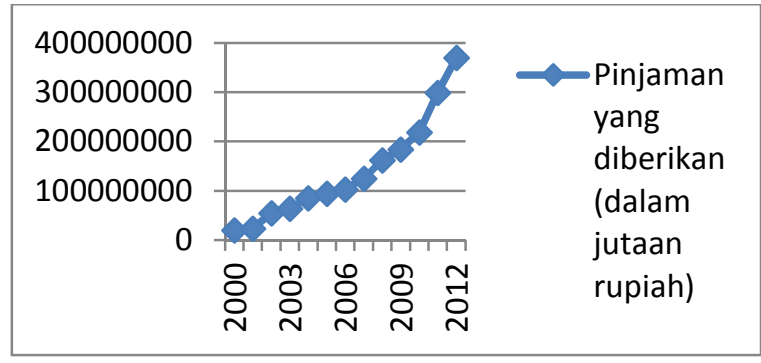

Berdasarkan gambar diatas, dapat terlihat bahwa terdapat peningkatan tingkat jumlah

\section{Pengujian hipotesis}

Tabel

Pengujian Hipotesis Autokorelasi

One-Sample Kolmogorov-Smirnov Test

\begin{tabular}{|ll|r|}
\hline & & $\begin{array}{r}\text { Unstandardiz } \\
\text { ed Residual }\end{array}$ \\
\hline $\mathrm{N}$ & 13 \\
Norma & Mean & .0000000 \\
$\mathrm{I}$ & Std. & Dev65682.443 \\
Param & Deviation & 8 \\
etersa,b & & .146 \\
Most Extreme & Absolute & .146 \\
Differences & Positive & -.114 \\
& Negative & .526 \\
Kolmogorov-Smirnov Z & .945 \\
\hline \multicolumn{2}{|l|}{ Asymp. Sig. (2-tailed) } \\
\hline
\end{tabular}

a. Test distribution is Normal.

b. Calculated from data.

kredit yang diberikan. Nilai jumlah kredit terendah terdapat pada tahun 2000 yaitu sebesar Rp. 20.286.000,00 (dalam jutaan rupiah). Sedangkan nilai jumlah kredit tertinggi terdapat pada tahun 2012 yaitu sebesar Rp. 370.570 .358 (dalam jutaan rupiah).

\section{Analisis Regresi Cost Of Loanable Fund dan ingkat Suku Bunga Sertifikat Bank Indonesia terhadap Jumlah Kredit.}

\section{Uji Asumsi Klasik}

Sebelum dilakukan pembentukan model regresi, sebelumnya dilakukan pengujian asumsi terlebih dahulu supaya model yang terbentuk memberikan estimasi yang BLUE. Pengujian asumsi ini terdiri atas tiga pengujian, yakni Uji Normalitas, Uji Autokorelasi, Uji Heteroskedastistias dan Uji Multikolinieritas.

\section{Uji Normalitas}

Uji normalitas data digunakan untuk memenuhi asumsi dilakukannya analisis regresi yang akan melakukan penaksiran sekaligus pengujian, dimana untuk kepentingan ini variabel yang bersifat random harus berdistribusi normal. 


\section{Uji Autokorelasi}

Secara harfiah autokorelasi berarti adanya korelasi antara anggota observasi satu dengan observasi lain yang berlainan waktu. Dalam kaitannya dengan asumsi metode kuadrat terkecil (OLS), autokorelasi merupakan korelasi antara satu residual dengan residual yang lain. Sedangkan satu asumsi penting metode OLS berkaitan dengan residual adalah tidak adanya hubungan antara residual satu dengan residual yang lain.

\begin{tabular}{|l|c|}
\hline \multicolumn{1}{|c|}{ Kesimpulan } & Daerah Pengujian \\
\hline Terdapat autokorelasi positif & $\mathrm{d}<\mathrm{d}_{\mathrm{L}}$ \\
\hline Ragu-ragu & $\mathrm{d}_{\mathrm{L}}<\mathrm{d}<\mathrm{d}_{\mathrm{U}}$ \\
\hline Tidak terdapat autokorelasi & $\mathrm{d}_{\mathrm{U}}<\mathrm{d}<4-\mathrm{d}_{\mathrm{U}}$ \\
\hline Ragu-ragu & $4-\mathrm{d}_{\mathrm{U}}<\mathrm{d}<4-\mathrm{d}_{\mathrm{L}}$ \\
\hline Terdapat autokorelasi negatif & $4-\mathrm{d}_{\mathrm{L}}<\mathrm{d}$ \\
\hline
\end{tabular}

Dari output SPSS diperoleh nilai d sebesar 0,635. Nilai ini kemudian dibandingkan dengan nilai $\mathrm{d}_{\mathrm{L}}$ dan $\mathrm{d}_{\mathrm{U}}$ pada tabel DurbinWatson. Untuk $\alpha=0.05, \mathrm{k}=2$ dan $\mathrm{n}=13$, diperoleh $d_{L}=0,89$ dan $d_{u}=1,53$. Karena $d$ terletak pada daerah sebelum $d_{L}(0,89)$ yang dapat disimpulkan bahwa model terdapat masalah autokorelasi positif.

Hasil pengujian autokorelasi ulang, dapat dilihat sebagai berikut.

Tabel

Uji Autokorelasi Ulang

Model Sumrtiary
\begin{tabular}{|l|c|r|r|r|r|}
\hline Mode & R & R Squar & $\begin{array}{l}\text { Adjusted } \\
\text { R Square }\end{array}$ the Estima & $\begin{array}{r}\text { Durbin- } \\
\text { Watson }\end{array}$ \\
\hline 1 & .950 & .903 & .883 & .30231 & 2.237 \\
\hline
\end{tabular}
a.Predictors: (Constant), In_sbi, In_colf
b.Dependent Variable: In_kredit

Dari output SPSS di atas diperoleh nilai d sebesar 2.237. Nilai ini kemudian dibandingkan dengan nilai $d_{\llcorner}$dan $d_{U}$ pada tabel Durbin-Watson. Untuk $\alpha=0.05, \mathrm{k}=2$ dan $\mathrm{n}=13$, diperoleh $\mathrm{d}_{\mathrm{L}}=0,89$ dan $\mathrm{d}_{\mathrm{u}}=$ 1,53. Karena d terletak antara $d_{u}(1,53)$ dan 4-du(2,47) yang dapat disimpulkan bahwa model tidak terdapat masalah autokorelasi.

\section{Uji Heteroskedastisitas}

Uji Heterokedastisitas bertujuan menguji apakah dalam model regresi terjadi ketidaksamaan variansi dari residual satu pengamatan ke pengamatan yang lain. Model regresi yang baik adalah yang homokesdatisitas atau tidak terjadi heterokedastisitas. Salah satu cara yang digunakan untuk mendeteksi ada atau tidaknya heterokedastisitas adalah dengan melihat grafik plot antar nilai prediksi variabel terikat (dependen) yaitu ZPRED dengan residualnya SRESID.

\section{Gambar}

Scatter Plot Uji Heteroskedastisitas

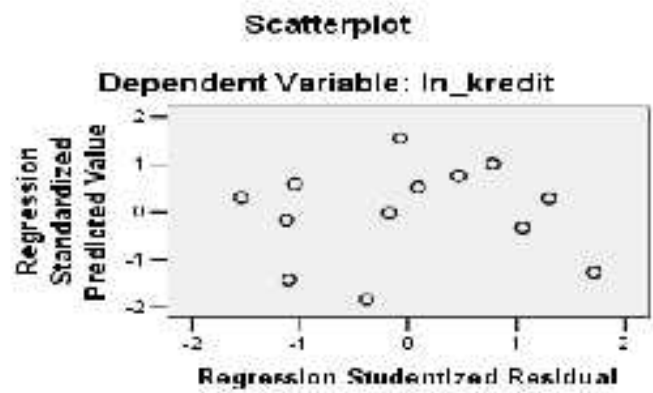

Dari gambar di tersebut, dapat dilihat bahwa dalam model tidak terdapat heteroskedastisitas karena pada gambar tidak ada pola yang jelas, serta titik-titik menyebar diatas dan dibawah angka 0 pada sumbu $Y$.

\section{Uji Multikolinieritas}

Uji multikolinieritas bertujuan untuk menguji apakah model regresi ditemukan adanya korelasi antar variabel bebas (independent). Model regresi yang baik seharusnya tidak terjadi korelasi diantara variabel bebas. Jika variabel bebas saling berkorelasi, maka variabel-variabel ini tidak ortagonal. Variabel ortagonal adalah variabel bebas yang nilai korelasi antar sesama variabel bebas sama dengan nol.

Untuk mendeteksi ada atau tidaknya multikolinieritas di dalam model regresi dapat dilihat dari nilai tolerance dan 
lawannya, yaitu variance inflation factor (VIF). Kedua ukuran ini menunjukkan setiap variabel bebas manakah yang dijelaskan oleh variabel bebas lainnya. Dalam pengertian sederhana setiap variabel bebas menjadi variabel terikat dan diregres terhadap variabel bebas lainnya. Tolerance mengukur variabilitas variabel bebas yang terpilih yang tidak dapat dijelaskan oleh variabel bebas lainnya. Jadi nilai tolerance yang rendah sama dengan nilai VIF yang tinggi (karena VIF $=1 /$ tolerance) dan menunjukkan adanya kolinieritas yang tinggi. Nilai cut-off yang umum dipakai adalah nilai tolerance 0,10 atau sama dengan nilai VIF diatas 10.

Dengan menggunakan program SPSS 20.0 for Windows, didapat output nilai VIF untuk masing-masing variabel bebas sebagai berikut.

Tabel 4.4

Uji Multikolinieritas

\begin{tabular}{|l|r|c|}
\multicolumn{2}{c|}{ Coefficients $^{\mathbf{a}}$} \\
\hline \multirow{2}{*}{ Model } & \multicolumn{2}{|c|}{ Collinearity Statistics } \\
\cline { 2 - 3 } & Tolerance & VIF \\
\hline (Const & & \\
ant) & & \\
COLF & .149 & 6.703 \\
SBI & .149 & 6.073 \\
\hline
\end{tabular}

a. Dependent Variable: Kredit

Hasil diatas menunjukkan bahwa nilai VIF masing-masing variabel bebas jauh di bawah 10, yakni $X_{1}\left(\right.$ COLF) $=6,703$ dan $X_{2}$ $(\mathrm{SBI})=6,703$. Maka dapat disimpulkan bahwa tidak terdapat multikolinieritas antar variabel bebas dalam model regresi.

\section{Analisis Regresi Linier Berganda}

Analisis ini dimaksudkan untuk mengetahui adanya pengaruh antara variabel $X$ terhadap variabel $Y$ Tujuannya untuk meramalkan atau memperkirakan nilai variabel dependen dalam hubungan sebabakibat terhadap nilai variabel lain.

\section{Analisis Koefisien Korelasi Ganda}

Untuk menentukan kriteria interpretasi nilai hubungan $r$ dan $R$, penulis mendasarkan

\begin{tabular}{|c|c|c|c|c|c|}
\hline \multicolumn{6}{|c|}{ Model Summary } \\
\hline Model & $\mathbf{R}$ & $\begin{array}{l}\text { R } \\
\text { Squar } \\
\text { e }\end{array}$ & $\begin{array}{c}\text { Adj } \\
\text { uste } \\
\text { d R } \\
\text { Squ } \\
\text { are }\end{array}$ & $\begin{array}{l}\text { Std. } \\
\text { Error } \\
\text { of the } \\
\text { Estim } \\
\text { ate }\end{array}$ & $\begin{array}{c}\text { Mode } \\
\text { I }\end{array}$ \\
\hline 1 & $\begin{array}{r}.950 \\
\mathrm{a}\end{array}$ & .903 & .883 & $\begin{array}{r}0.3023 \\
1\end{array}$ & 1 \\
\hline
\end{tabular}

a. Predictors: (Constant), In_sbi, In_colf

b. Dependent Variable: In_kredit

pada ketepatan yang dikemukakan oleh Sugiyono (2005:84), yaitu :

Tabel Interpretasi Nilai Hubungan $r$ dan $\mathrm{R}$

\begin{tabular}{|c|c|}
\hline $\begin{array}{c}\text { Besarnya Nilai Hubungan } \\
\text { r dan R }\end{array}$ & Interpretasi \\
\hline $0,000-0,200$ & Sangat Lemah \\
\hline $0,201-0,400$ & Lemah \\
\hline $0,401-0,600$ & Cukup Kuat \\
\hline $0,601-0,800$ & Kuat \\
\hline $0,801-1,000$ & Sangat Kuat \\
\hline
\end{tabular}

Dari tabel diatas didapat nilai koefisien korelasi ganda antara variabel bebas dengan variabel Jumlah Kredit sebesar 0,950. Berdasarkan tabel interpretasi koefisien korelasi, maka koefisien korelasi sebesar 0,950 menunjukkan adanya hubungan positif yang sangat kuat (diantara $0,801-1,000)$ antara variabel $X$ terhadap variabel $Y$.

\section{Persamaan Regresi Linier Berganda}

Model regresi berganda yang akan dibentuk adalah sebagai berikut:

$\mathrm{Y}=\mathrm{b}_{0}+\mathrm{b}_{1} \mathrm{X}_{1}+\mathrm{b}_{2} \mathrm{X}_{2}$

Dimana:

$\mathrm{Y}=$ Jumlah Kredit

$\mathrm{X}_{1}=$ Cost of Loanable Fund

$\mathrm{X}_{2}=$ tingkat suku bunga Sertifikat BI

$\mathrm{B}_{0}=$ Bilangan konstanta

$\mathrm{B}_{1}, \mathrm{~B}_{2}=$ Koefisien regresi

Dengan menggunakan program SPSS 20.00 for Windows, diperoleh hasil koefisien regresi sebagai berikut: 
Tabel

Perhitungan Koefisien Regresi

Coefficients $^{\mathrm{a}}$

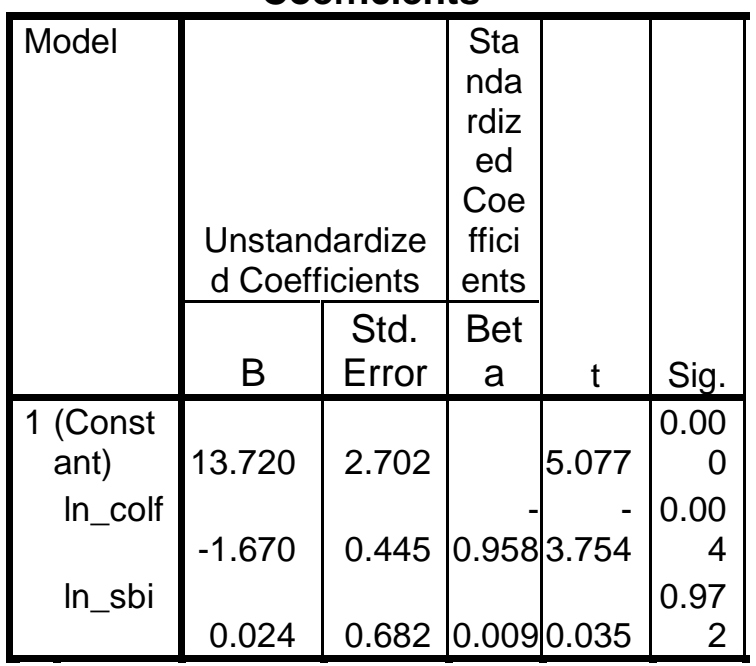

a. Dependent Variable: In_kredit

Dari output di atas diketahui nilai kontstanta dan koefisien regresi sehingga dapat dibentuk persamaan regresi linier berganda sebagai berikut:

$Y=13.720-1.670 \ln \left(X_{1}\right)+0.024 \ln \left(X_{2}\right)$

Persamaan di atas dapat diartikan sebagai berikut:

$b_{0}=13.720$ artinya jika variabel $X_{1}$ dan $\mathrm{X}_{2}$ bernilai nol (0), maka variabel $\mathrm{Y}$ akan bernilai 13.720 satuan.

$\mathrm{b}_{1}=-1.670$ artinya jika In Cost of Loanable Fund $\left(\mathrm{X}_{1}\right)$ meningkat sebesar satu satuan dan variabel lainnya konstan, maka variabel $Y$ akan menurun sebesar - 1.670 satuan.

$b_{2}=0.024$ artinya jika In tingkat suku bunga Sertifikat Bank Indonesia $\left(X_{2}\right)$ meningkat sebesar satu satuan dan variabel lainnya konstan, maka variabel $\mathrm{Y}$ akan menurun sebesar 0.024 satuan.

\section{Pengujian Hipotesis Simultan (Uji F)}

$\mathrm{H}_{0} \quad$ : Cost of Loanable Fund dan tingkat suku bunga Sertifikat Bank Indonesia, secara bersama-sama tidak berpengaruh signifikan terhadap Jumlah Kredit.

$\mathrm{H}_{1} \quad$ : Cost of Loanable Fund dan tingkat suku bunga Sertifikat Bank Indonesia, secara bersama-sama berpengaruh signifikan terhadap Jumlah Kredit.

Tingkat signifikan $(\alpha)$ sebesar $5 \%$

Dengan menggunakan program SPSS 20.00 for windows, diperoleh output sebagai berikut:

Tabel

Perhitungan Hipotesis Regresi Simultan

\begin{tabular}{|c|c|c|c|c|c|c|}
\hline \multicolumn{7}{|c|}{ ANOVA } \\
\hline Model & & $\begin{array}{r}\text { Sum of } \\
\text { Squares }\end{array}$ & df & Mean Square & $\mathrm{F}$ & Sig. \\
\hline \multirow[t]{3}{*}{1} & Regression & 8.485 & 2 & 4.242 & 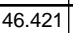 & $.000^{a}$ \\
\hline & Residual & .914 & 10 & .091 & & \\
\hline & Total & 9.399 & 12 & & & \\
\hline
\end{tabular}

Berdasarkan output di atas diketahui nilai $F_{\text {hitung }}$ sebesar 46,421 dengan $p$-value (sig) 0,000. Dengan $\alpha=0,05$ serta derajat kebebasan $\mathrm{v} 1=10(\mathrm{n}-(\mathrm{k}+1))$ dan $\mathrm{v}_{2}=2$, maka di dapat $F_{\text {tabel }} 19,396$. Dikarenakan nilai $F_{\text {hitung }}>F_{\text {tabel }}(46,421>19,396)$ maka $\mathrm{H}_{0}$ ditolak, artinya variabel bebas secara simultan berpengaruh signifikan terhadap Jumlah Kredit.

Pengujian Hipotesis Parsial (Uji t)

Dengan menggunakan program SPSS

Coefficients $^{\mathrm{a}}$

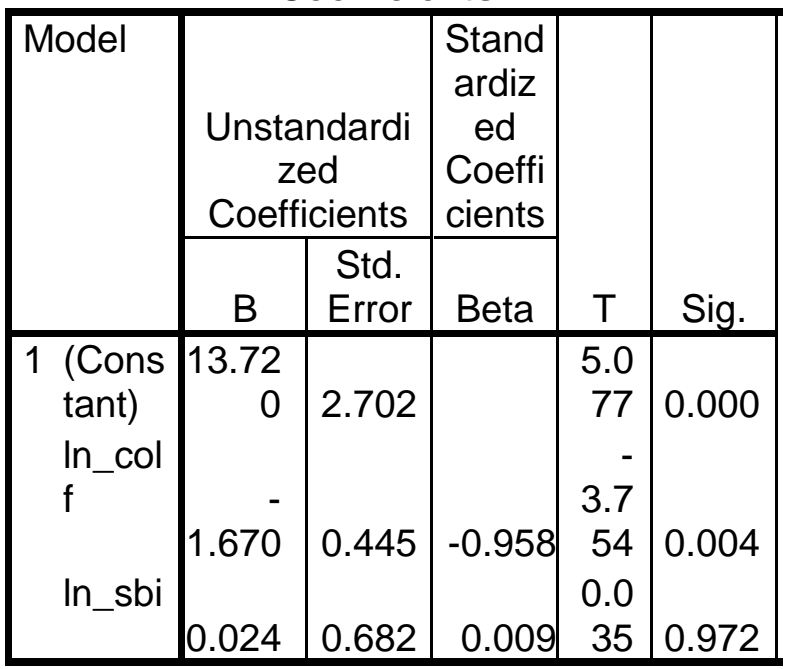

a. Dependent Variable: In_kredit

berikut:

20.00 for windows, diperoleh output sebagai 
Tabel Perhitungan Hipotesis Regresi Parsial

- Pengujian hipotesis variabel $\mathrm{X}_{1}$ (Cost of Loanable Fund)

$\mathrm{H}_{0}$ : Cost of Loanable Fund tidak berpengaruh signifikan terhadap Jumlah kredit.

$\mathrm{H}_{1}$ : Cost of Loanable Fund berpengaruh signifikan terhadap Jumlah Kredit.

Tingkat signifikan $(\alpha)$ sebesar $5 \%$, dan derajat kebebasan $(v)=11(n-2)$ didapat nilai tabel 2,201.

Dari output SPSS diatas diperoleh nilai $t_{\text {hitung }}$ untuk $X_{1}$ sebesar -3.754 dan tabel 2,201. Dikarenakan nilai -t hitung $_{<}<-t_{\text {tabel}}$, maka $\mathrm{H}_{0}$ ditolak, artinya Cost of Loanable Fund berpengaruh terhadap Jumlah Kredit secara signifikan.

Pengujian hipotesis variabel $\mathrm{X}_{2}$ (tingkat suku bunga Sertifikat Bank Indonesia)

$\mathrm{H}_{0} \quad$ : tingkat suku bunga Sertifikat Bank Indonesia tidak berpengaruh signifikan terhadap Jumlah Kredit .

$\mathrm{H}_{1} \quad$ : tingkat suku bunga Sertifikat Bank Indonesia berpengaruh signifikan terhadap Jumlah Kredit.

Dari output SPSS diatas diperoleh nilai thitung untuk $\mathrm{X}_{2}$ sebesar 0.035 dan $t_{\text {tabel }}$ 2,201.

Dikarenakan nilai $t_{\text {nitung }}$ berada pada $-t_{\text {tabel }}$ dan $\mathrm{t}_{\text {tabel }}$ maka $\mathrm{H}_{0}$ diterima, artinya tingkat suku bunga Sertifikat Bank Indonesia tidak berpengaruh terhadap Jumlah Kredit secara signifikan.

\section{Analisis Koefisien Determinasi}

1. Koefisien Determinasi Simultan

Setelah diketahui nilai $R$ sebesar 0,950, maka koefisien determinasi dapat dihitung menggunakan rumus sebagai berikut:
Tabel Perhitungan Koefisien Determinasi Simultan

\begin{tabular}{|l|r|r|r|r|r|}
\hline Model & $\mathrm{R}$ & $\mathrm{R}$ Square & $\begin{array}{r}\text { Adjusted } \\
\text { R Square }\end{array}$ & $\begin{array}{r}\text { Std. Error of } \\
\text { the Estimate }\end{array}$ & $\begin{array}{r}\text { Durbin- } \\
\text { Watson }\end{array}$ \\
\hline 1 & $.950^{\mathrm{a}}$ & .903 & .883 & .30231 & 2.237 \\
\hline
\end{tabular}
a. Predictors: (Constant), In_sbi, In_colf
b. Dependent Variable: In_kredit

$$
\begin{aligned}
\mathrm{KD} & =\mathrm{R}^{2} \times 100 \% \\
& =(0,950)^{2} \times 100 \% \\
& =90,3 \%
\end{aligned}
$$

Dengan demikian, maka diperoleh nilai KD sebesar 90,3\% yang menunjukkan arti bahwa Cost of Loanable Fund dan tingkat suku bunga Sertifikat Bank Indonesia memberikan pengaruh simultan (bersamasama) sebesar 90,3\% terhadap Jumlah Kredit . Sedangkan sisanya sebesar 9,7\% dipengaruhi oleh faktor lain yang diabaikan penulis.

\section{Koefisien Determinasi Parsial}

Dari hasil uji individu diatas diketahui bahwa variabel $\mathrm{X}_{1}$ (Cost of Loanable Fund) terhadap variabel $Y$ (Jumlah Kredit) memiliki pengaruh positif sebesar 0,950 dan $\mathrm{X}_{2}$ (tingkat suku bunga Sertifikat Bank Indonesia) terhadap variabel $Y$ (Jumlah Kredit) memiliki pengaruh negatif sebesar 0,875 .

Tabel Perhitungan Koefisien Koefisien Determinasi Parsial

\section{Coefficients $^{a}$}

\begin{tabular}{|l|r|r|r|}
\hline \multirow{2}{*}{ Model } & \multicolumn{3}{|c|}{ Correlations } \\
\cline { 2 - 4 } & Zero-order & Partial & Part \\
\hline 1 (Constant) & & & \\
In_colf & -.950 & -.765 & -.370 \\
In_sbi & -.875 & -.011 & -.003 \\
\hline
\end{tabular}

a. Dependent Variable: In_kredit

$\begin{aligned} \mathrm{KD}\left(\mathrm{X}_{1}\right) & =\mathrm{R}^{2} \times 100 \% \\ & =(-0,950)^{2} \times 100 \% \\ & =90.25 \% \\ \mathrm{KD}\left(\mathrm{X}_{2}\right) \quad & =\mathrm{R}^{2} \times 100 \% \\ & =(-0,875)^{2} \times 100 \% \\ & =76.56 \%\end{aligned}$




\section{KESIMPULAN DAN SARAN}

\section{KESIMPULAN}

Dengan demikian, maka diperoleh nilai KD Cost of Loanable Fund sebesar 90.25\% yang menunjukkan arti bahwa Cost of Loanable Fund memberikan pengaruh secara parsial sebesar $90.25 \%$ terhadap Jumlah Kredit, sedangkan tingkat suku bunga Sertifikat Bank Indonesia mberikan pengaruh secara parsial sebesar $76.56 \%$ terhadap Jumlah Kredit.

\section{SARAN}

Dalam pemberian kredit, bank sebaiknya menetapkan tingkat suku bunga atau Base Lending Rate (BLR) guna meningkatkan profitabilitas. Adapun salah satu komponen yang menentukan Base Lending Rate adalah Cost of Loanable Fund (COLF) yaitu Biaya Dana yang harus dibayar oleh bank untuk setiap rupiah dana setelah dikurangi dengan bagian dana yang harus dipelihara bank sebagai cadangan wajib.

\section{DAFTAR PUSTAKA}

[1] Ali Masyhud. 2004. Asset Liability Management. Jakarta: PT Elex Media Komputindo

[2] Dendawijaya, Lukman. 2003.

Manajemen Perbankan. Jakarta: Ghalia Indonesia

[3] Firdaus, Rahmat dan Ariyanti, Maya. 2004. Manajemen Perkreditan Bank Umum Bandung; ALFABETA.

[4] Joseph, Charles. Target Vs Asumsi Inflasi, Nilai Tukar dan Suku Bunga SBI di RAPBN 2005. Dalam http://www.perbendaharaan.go.id/modu //terkini/index.

[5] Kasmir.2004. Manajemen Perbankan. Jakarta: PT Raja Grafindo Persada
[6] Nugroho, Agung Bhuono. 2005. Strategi Jitu Memilih Metode Statistik Penelitian dengan SPSS. Yogyakarta: ANDI.

[7] Santoso, Singgih. 2001. Buku Latihan SPSS Statistik Parametrik. Jakarta. PT Elex Media Komputindo.

[8] Siamat, Dahlan. 2001. Manajemen Lembaga Keuangan. Jakarta : Fakultas Ekonomi Universitas Indonesia

[9] Sri, Haryanti. 2005. Bisnis Bank. Jakarta: PT Panangian Media Properti (PMP).

[10] Sugiyono. 2005. Metode Penelitian Bisnis. Bandung: ALFABETA, CV.

[11] Sulaiman, Wahid. 2004. Analisis Regresi Menggunakan SPSS. Yogyakarta: ANDI.

[12] Sumantyo, Riwi.2004. Pemilu dan Tren Rupiah.

http://www.suaramerdeka.com/harian/ 0401/02/eko11.htm.

[13] Suyatno, Thomas, dkk. 2003. Dasardasar Perkreditan. Jakarta: PT. Gramedia Pustaka Utama

[14] Taswan. 2003. Akuntansi Perbankan. Semarang: UPP AMP YKPN. 